women using different methods of contraception - an interim report. f Biosoc Sci 1976;8:373-427.

13 Vessey MP, McPherson K, Villard-Mackintosh L, Yeates D. Oral contracep tives and breast cancer: latest findings in a large cohort study. $\mathrm{Br} F$ Cancer $1989 \cdot 59 \cdot 613-7$

14 Vessey MP, Lawless M, McPherson K, Yeates D. Neoplasia of the cervix uteri and contraception: a possible adverse effect of the pill. Lancet 1983;ii:930-4.

15 Vessev M, Metcalfe A, Wells C, McPherson K, Westhoff C, Yeates D). Ovarian neoplasms, functional ovarian cysts, and oral contraceptives. Br Med 1987:294:1518-20.

16 Vessey MP, McPherson K, Johnson B. Mortality among women participating in the Oxford-Family Planning Association contraceptive study. Lance 1977;ii:731-3.

17 McPherson K, Vessey MP, Neil A, Doll R, Jones I., Roberts M. Early oral contraceptive use and breast cancer: results of another case-control study. $B r \mathcal{F}$ Cancer 1987;56:653-60.

18 Vessey M, Mant D, Smith A, Yeates D. Oral contraceptives and venous thromboembolism: findings in a large prospective studv. $\mathrm{Br} \mathrm{Med}$ $1986 ; 292: 526$
19 Vessey MP, Lawless $M$, Yeates D. Oral contraceptives and stroke: findings in a large prospective study. Br Med f 1984;289:530-1.

20 Croft P. Hannaford PC. Risk factors for acute myocardial infarction in women: evidence from the Royal College of General Practitioners' oral contraception evidence from the Royal College of

21 Slon D, Shapiro S, Kaufua DW, Rosenberg L, Miettinen OS, Stolley PD. Risk of myocardial infarction in relation to current and discontinued use of Risk of myocardial infarction in relation to current

22 Stampfer MJ, Willet WC, Colditz GA, Speizer FE, Hennekens $\mathrm{CH}$. A prospective study of past use of oral contraceptive agents and risk of prospective study of past use of oral contraceptive a

23 Goldzieher JW. Oral contraceptive hazards-1981. Fertil Steril 1981;35:275-6. 24 Wiseman RA, MacRae KD. Oral contraceptives and the decline in mortality from circulatory disease. Fertil Steril 1981;35:277-83.

25 Vessey MP, McPherson K, Lawless M, Yeates D. Oral contraception and serious psychiatric illness: absence of an association. $\mathrm{Br} \mathcal{F}$ Psychiatr 1985; 146:45-9.

(Accepted II October 1989)

\title{
Snoring in children: association with respiratory symptoms and passive smoking
}

\author{
Giuseppe M Corbo, Fulvia Fuciarelli, Antonio Foresi, Fernando De Benedetto
}

\begin{abstract}
Objective-To investigate the relation between snoring and various respiratory symptoms and passive parental smoking.

Design-Data were collected by questionnaire.

Setting-Primary schools in Guardiagrele and

Francavilla in the Abruzzi region in central Italy.

Subjects-1615 Children aged 6-13 years were categorised according to whether they snored often; occasionally apart from with colds; only with colds; or never.

Results -118 Children were habitual snorers and 137 were reported to snore apart from when they had colds. Never snorers $(n=822)$ were significantly older than children in other categories. Snoring was significantly associated with rhinitis, production of cough and sputum, previous tonsillectomy, and passive parental smoking. Of the habitual snorers, 82 were exposed to passive smoking. The prevalence of habitual snoring increased significantly with the number of cigarettes smoked by parents (from 5.5\% in moderate smoking households to $8.8 \%$ in heavy smoking households).

Conclusions-Snoring is quite common in children. The dose-effect relation of smoking and snoring shown in this study adds weight to a further adverse effect of parental smoking on children's health.
\end{abstract}

Divisione di Pneumologia Pediatrica, Centro

Auxologico Italiano, 28044

Verbania (NO), Italy

Giuseppe M Corbo, MD,

senior registrar

Antonio Forest, MD, registrar

Istituto di Clinica Medica, Servizio di Fisiopatologia

Respiratoria, 66110 Chieti, Italy

Fulvia Fuciarelli, MD

attending physician

Fernando De Benedetto,

$\mathrm{MD}$, senior registrar

Correspondence and requests for reprints to: Dr Corbo.

BrMed J 1989;299:1491-4

\section{Introduction}

Although snoring is often regarded as trivial, it has been associated with hypertension, ${ }^{1-5}$ heart disease, ${ }^{2-6}$ and stroke, ${ }^{6}$ and it is considered to be the first step towards the development of the sleep apnoea syndrome..$^{7.9}$ Heavy snorers can suffer obstructive apnoea and alveolar hypoventilation during sleep as well as an increase in pulmonary and systemic arterial pressures. $^{70}$

Bloom and coworkers have found that cigarette smoking, obesity, male gender, and age are risk factors for snoring and that snoring is associated with cough and sputum production. ${ }^{10}$ Snoring is common in adults $\left(24-71 \%\right.$ of men and $14-52 \%$ of women $\left.^{4}\right)$, and the prevalence tends to increase with age.'

Snoring during childhood has been investigated only in selected clinical samples, and it has been found to be associated with sleep apnoea and related symptoms such as excessive daytime somnolence, hyperactivity, and behavioural or intellectual changes. ${ }^{11 \cdot 13}$ These observations suggested that chronic snoring in a child should prompt appropriate investigation and treatment. ${ }^{14}$ Despite evidence of the clinical consequences of snoring no data are available regarding the prevalence of snoring in a general population of children.

We investigated the prevalence of snoring in a general population sample of children aged 6-13 years and the occurrence of snoring in association with age, sex, respiratory symptoms, and parental passive smoking.

\section{Methods}

The study was conducted in two towns in the Abruzzo region (Guardiagrele and Francavilla) in central Italy. We studied the overall population of schoolchildren in the first degree (aged 6-11 years) (1907 subjects: 964 boys and 943 girls) and in the second degree (aged 10-13 years) (455 subjects: 235 boys and 220 girls). The rate of compliance was $97 \%$. To avoid possible bias towards non-snorers we excluded from the analysis children who had been sleeping alone because the prevalence of snoring in these children was significantly lower than in children sharing a bedroom with siblings or parents $(3.6 \% v$ $\left.7 \cdot 3 \% ; \chi^{2}=10 \cdot 7 ; p=0.0011\right)$. The excluded sample $(747$ subjects: 389 boys and 358 girls) did not differ as regards age, sex, respiratory symptoms, and smoking habits of the parents from the examined group ( 1615 subjects: 810 boys and 805 girls, aged 6-13 years). Data on snoring, respiratory symptoms, and parental smoking were obtained from a modified American Thoracic Society children's questionnaire, ${ }^{15}$ which was completed by the parents.

\section{DEFINITIONS}

The question concerning snoring was: "Does your child ever snore?" On the basis of the answer four categories were formed: (1) never; (2) only with colds; (3) occasionally apart from with colds; and (4) often. Children included in the last category were defined as habitual snorers.

Asthma was defined as an affirmative response to a question about whether the child had been told that he or she had asthma by a doctor. Rhinitis was defined in terms of response to the following question: "Has your child ever had rhinitis (stuffy and running nose, itchy eyes, sneezing)?" Cough and phlegm were defined as cough or phlegm that occurred apart from with colds. 
Lastly, parents were asked if their child had had a tonsillectomy because of throat infections.

Households in which both parents had never smoked were classified as non-smoking; those with either one parent or both parents who were current smokers (that is, currently smoking at least one cigarette each day or having stopped smoking within the past 12 months) were classified as smoking. Smoking households with smokers were classified into moderate (summed total for both parents of less than 20 cigarettes each day) and heavy smokers (summed total of 20 cigarettes each day or more). Duration of parental smoking during the child's lifetime was also recorded.

\section{STATISTICAL ANALYSIS}

The mean age of the children in the four categories of snoring was compared by variance analysis and orthogonal comparisons. ${ }^{16}$ The categories were analysed with reference to sex and parental passive smoking and also to asthma, rhinitis, cough and phlegm, and tonsillectomy by giving an arbitrary score to each category (never $=-3$, only with colds $=-1$, sometimes apart from with colds $=1$, and often $=3$ ), and the significance of linear trends was tested. ${ }^{17} \mathrm{We}$ present the odds ratio referring to habitual snorers compared with non-snorers with $95 \%$ confidence intervals. ${ }^{18}$ As smoking has been implicated as a risk factor for snoring ${ }^{10}$ stratified techniques were utilised to adjust for the effect of passive smoking. ${ }^{19} \mathrm{We}$ calculated $95 \%$ confidence intervals for the MantelHaenszel weighted odds ratio. ${ }^{20}$ Children who snored only with colds and children who snored sometimes apart from colds were excluded from the stratified analysis.

The prevalence of habitual snoring compared with that of never snoring was compared in children from

TABLE I-Prevalence of snoring in children $(n=1615)$ according to age and sex

\begin{tabular}{lcccc}
\hline & Never & $\begin{array}{c}\text { Only with } \\
\text { colds }\end{array}$ & $\begin{array}{c}\text { Apart from } \\
\text { with colds }\end{array}$ & Habitual \\
\hline No (\%) of children & $822(50 \cdot 9)$ & $538(33 \cdot 3)$ & $137(8 \cdot 5)$ & $118(7 \cdot 3)$ \\
95\% Confidence interval (\%) & 48 to 53 & 31 to 36 & 7 to 10 & 6 to 9 \\
No(\%) boys & $398(49 \cdot 1)$ & $286(35 \cdot 3)$ & $67(8 \cdot 3)$ & $59(7 \cdot 3)$ \\
95\% Confidence interval (\%) & 46 to 52 & 32 to 38 & 6 to 10 & 6 to 9 \\
No(\%) of girls & $424(52 \cdot 7)$ & $252(31 \cdot 3)$ & $70(8 \cdot 7)$ & $59(7 \cdot 3)$ \\
95\% Confidence interval (\%) & 49 to 56 & 28 to 34 & 7 to 11 & 6 to 9 \\
Mean (SD) age (years) & $9 \cdot 73(1 \cdot 75)$ & $9 \cdot 31(1.75)$ & $9 \cdot 33(1 \cdot 78)$ & $9 \cdot 39(1 \cdot 78)$ \\
95\% Confidence interval (\%) & $9 \cdot 6$ to $9 \cdot 86$ & $9 \cdot 16$ to $9 \cdot 46$ & $9 \cdot 03$ to $9 \cdot 64$ & $9 \cdot 06$ to $9 \cdot 72$ \\
\hline
\end{tabular}

non-smoking households and households with moderate smokers and heavy smokers by the $\chi^{2}$ test for trend. ${ }^{17}$

Weights of zero were assigned to the non-smoking group and the median numbers of cigarettes smoked to the two smoking groups (10 and 22 , respectively). A $\mathrm{p}$ value $<0.05$ was considered significant.

\section{Results}

In all, 118 children $(7 \cdot 3 \% ; 59$ boys and 59 girls) were habitual snorers and $137(8 \cdot 5 \% ; 67$ boys and 70 girls $)$ were reported to snore apart from when they had colds (table I). Mean age differed significantly in the four snoring categories (variance analysis $F=7 \cdot 27 ; p=$ $0 \cdot 0002)$. Never snorers were significantly older than children in other categories $(F=19 \cdot 7 ; p<0 \cdot 001)$. There was no difference in the prevalence of snoring between girls and boys $\left(\chi^{2}=0 \cdot 43\right)$.

There was a relation between prevalence of snoring and several respiratory symptoms (table II). Snoring was significantly associated with rhinitis $\left(\chi^{2}=23.9\right.$; $\mathrm{p}<0.0005)$ : rhinitic children were more than twice as likely to be habitual snorers (odds ratio $=2.93$ : $95 \%$ confidence interval $1 \cdot 70$ to $5 \cdot 00$ ). The relation between rhinitis and habitual snoring was not affected by the presence of passive smoking (table III).

Asthmatic children were more likely to be snorers than other children $\left(\chi^{2}=5.6 ; p<0.025\right)$, but risk of habitual snoring did not achieve significance (odds ratio $=1.88 ; 0.98$ to 3.50 ). Cough and sputum production were associated with an increased prevalence of snoring $\left(\chi^{2}=11.06 ; p<0.001\right)$ (table II). The risk of habitual snoring was also significantly increased (odds ratio $=1 \cdot 84 ; 1 \cdot 09$ to $3 \cdot 10$ ). Cough and sputum production was still related to habitual snoring after adjusting for passive smoking (table III), but the association was stronger in children whose parents did not smoke $(2.52 ; 1.02$ to 6.07$)$ than in children exposed to passive smoking $(1.56 ; 0.79$ to 3.03$)$.

Prevalence of snoring was also increased in children who had had tonsillectomy $\left(\chi^{2}=14.05 ; \mathrm{p}<0.0005\right)$ (table II). The prevalence of habitual snoring was increased about twofold $(12.6 \% v 6.5 \%$; odds ratio $=$ $2.66 ; 1.60$ to 4.47 ) The relation of tonsillectomy to habitual snoring was not affected by the presence of passive smoking (table III), but the risk of habitual snoring was higher in children from smoking house-

TABLE II - Prevalence of snoring in children $(n=1615)$ according to presence of various respiratory symptoms

\begin{tabular}{|c|c|c|c|c|c|c|c|c|}
\hline & $\begin{array}{c}\text { Never } \\
(\mathrm{n}=822)\end{array}$ & $\begin{array}{l}\text { Only with } \\
\text { colds } \\
(\mathbf{n}=538)\end{array}$ & $\begin{array}{c}\text { Apart from } \\
\text { with colds } \\
(\mathrm{n}=137)\end{array}$ & $\begin{array}{l}\text { Habitual } \\
(\mathrm{n}=118)\end{array}$ & $\chi^{2}$ Trend & p Value & Odds ratio ${ }^{\star}$ & $\begin{array}{c}\text { Confidence } \\
\text { interval }\end{array}$ \\
\hline $\begin{array}{l}\text { No (\%) with rhinitis } \\
95 \% \text { Confidence interval (\%) }\end{array}$ & $\begin{array}{r}69(8 \cdot 4) \\
6 \text { to } 10\end{array}$ & $\begin{array}{l}76(14 \cdot 1) \\
11 \text { to } 17\end{array}$ & $\begin{array}{l}23(16 \cdot 8) \\
10 \text { to } 23\end{array}$ & $\begin{array}{l}35(29 \cdot 7) \\
21 \text { to } 38\end{array}$ & $23 \cdot 90$ & $<0.005$ & $2 \cdot 93$ & 1.71 to 5.00 \\
\hline $\begin{array}{l}\text { No (\%) with asthma } \\
95 \% \text { Confidence interval (\%) }\end{array}$ & $\begin{array}{l}59(7 \cdot 2) \\
5 \text { to } 9\end{array}$ & $\begin{array}{l}54(10 \cdot 0) \\
7 \text { to } 12\end{array}$ & $\begin{array}{c}14(10 \cdot 2) \\
5 \text { to } 15\end{array}$ & $\begin{array}{c}15(12 \cdot 7) \\
7 \text { to } 19\end{array}$ & $5 \cdot 60$ & $<0.025$ & $1 \cdot 88$ & 0.98 to 3.50 \\
\hline $\begin{array}{l}\text { No }(\%) \text { with cough or phlegm } \\
95 \% \text { Confidence interval }(\%)\end{array}$ & $\begin{array}{c}100(12 \cdot 2) \\
10 \text { to } 14\end{array}$ & $\begin{array}{c}102(19 \cdot 9) \\
16 \text { to } 23\end{array}$ & $\begin{array}{l}25(18 \cdot 2) \\
12 \text { to } 25\end{array}$ & $\begin{array}{l}24(20 \cdot 3) \\
13 \text { to } 27\end{array}$ & $11 \cdot 06$ & $<0.001$ & 1.84 & 1.09 to 3.10 \\
\hline $\begin{array}{l}\text { No }(\%) \text { who had had tonsillectomy } \\
95 \% \text { Confidence interval }(\%)\end{array}$ & $\begin{array}{r}79(9 \cdot 6) \\
8 \text { to } 12\end{array}$ & $\begin{array}{l}87(16 \cdot 2) \\
13 \text { to } 19\end{array}$ & $\begin{array}{c}15(10 \cdot 9) \\
6 \text { to } 16\end{array}$ & $\begin{array}{l}26(22) \\
15 \text { to } 29\end{array}$ & 14.05 & $<0.0005$ & $2 \cdot 66$ & 1.60 to 4.47 \\
\hline
\end{tabular}

^Never snoring $v$ habitual snoring.

TABLE III-Relative risk (odds ratios) of habitual snoring for children with rhinitis, cough or phlegm and tonsillectomy after adjustment for passive smoking

\begin{tabular}{|c|c|c|c|c|c|}
\hline & $\begin{array}{l}\text { Children from } \\
\text { smoking } \\
\text { households }\end{array}$ & $\begin{array}{l}\text { Children from } \\
\text { non-smoking } \\
\text { households }\end{array}$ & All children & $\chi^{2 \star}$ & $\mathrm{p}$ Value \\
\hline $\begin{array}{l}\text { Rhinitis } \\
95 \% \text { Confidence interval }\end{array}$ & $\begin{array}{c}2 \cdot 78 \\
1 \cdot 42 \text { to } 5 \cdot 43\end{array}$ & $\begin{array}{c}3 \cdot 22 \\
1 \cdot 23 \text { to } 8 \cdot 22\end{array}$ & $\begin{array}{c}2.92 \\
1.75 \text { to } 4.85\end{array}$ & $16 \cdot 9$ & $<0.0005$ \\
\hline $\begin{array}{l}\text { Cough or phlegm } \\
95 \% \text { Confidence interval }\end{array}$ & $\begin{array}{c}1.56 \\
0.79 \text { to } 3.03\end{array}$ & $\begin{array}{c}2.52 \\
1.02 \text { to } 6.07\end{array}$ & $\begin{array}{c}1 \cdot 84 \\
1 \cdot 12 \text { to } 3 \cdot 01\end{array}$ & $5 \cdot 23$ & $<0.025$ \\
\hline $\begin{array}{l}\text { Tonsillectomy } \\
95 \% \text { Confidence interval }\end{array}$ & $\begin{array}{c}3 \cdot 21 \\
1 \cdot 70 \text { to } 5 \cdot 98\end{array}$ & $\begin{array}{c}1.53 \\
0.49 \text { to } 4.49\end{array}$ & $\begin{array}{c}2 \cdot 62 \\
1 \cdot 59 \text { to } 4 \cdot 32\end{array}$ & 13.90 & $<0.0005$ \\
\hline
\end{tabular}

*Mantel-Haenszel test. holds $(3 \cdot 21 ; 1 \cdot 70$ to 5.98$)$ than in children from nonsmoking households $(1 \cdot 53 ; 0.49$ to $4 \cdot 49)$. •

Of the total sample, 959 children $(59 \cdot 4 \%)$ had either one parent or both parents who currently smoked (table IV). Snoring was closely related to passive parental smoking. Children of smoking parents were more likely to be snorers than children whose parents never smoked $\left(\chi^{2}=18.5 ; \mathrm{p}<0.0005\right)$. Of the 118 habitual snorers $82(69 \%)$ were exposed to passive smoking $(1.85 ; 1.20$ to 2.89$)$. Complete data on the daily amount of cigarettes smoked by parents were available for 922 of the 959 children (96\%) (table IV). 


\begin{tabular}{|c|c|c|c|c|c|c|c|c|}
\hline & Never & $\begin{array}{l}\text { Only with } \\
\text { colds }\end{array}$ & $\begin{array}{l}\text { Apart from } \\
\text { with colds }\end{array}$ & Habitual & $\gamma$ Trend & $\mathrm{p}$ Value & Odds ratio ${ }^{\star}$ & $\begin{array}{c}\text { Confidence } \\
\text { interval }\end{array}$ \\
\hline $\begin{array}{l}\text { No }(\%) \text { non-smokers } \\
95 \% \text { Confidence interval (\%) }\end{array}$ & $\begin{array}{c}368(44 \cdot 8) \\
41 \text { to } 48\end{array}$ & $\begin{array}{l}215(40 \cdot 0) \\
36 \text { to } 44\end{array}$ & $\begin{array}{l}37(27 \cdot 0) \\
20 \text { to } 34\end{array}$ & $\begin{array}{l}36(30 \cdot 5) \\
22 \text { to } 39\end{array}$ & & & & \\
\hline $\begin{array}{l}\text { Total No (\%) smokers } \\
95 \% \text { Confidence interval (\%) }\end{array}$ & $\begin{array}{l}454(55 \cdot 2) \\
52 \text { to } 58\end{array}$ & $\begin{array}{l}323(60 \cdot 0) \\
56 \text { to } 64\end{array}$ & $\begin{array}{c}100(73 \cdot 0) \\
66 \text { to } 80\end{array}$ & $\begin{array}{l}82(69 \cdot 5) \\
61 \text { to } 78\end{array}$ & $18 \cdot 5$ & $<0.0005$ & $1 \cdot 85$ & $1 \cdot 2$ to $2 \cdot 8$ \\
\hline $\begin{array}{l}\text { No (\%) moderate smokers } \dagger \\
95 \% \text { Confidence interval (\%) }\end{array}$ & $\begin{array}{c}209(26 \cdot 1) \\
23 \text { to } 29\end{array}$ & $\begin{array}{l}153(29 \cdot 1) \\
25 \text { to } 33\end{array}$ & $\begin{array}{l}47(34 \cdot 8) \\
27 \text { to } 43\end{array}$ & $\begin{array}{l}37(32 \cdot 2) \\
24 \text { to } 41\end{array}$ & $13 \cdot 4$ & $<0.0005$ & $1 \cdot 81$ & $1 \cdot 08$ to $3 \cdot 0$ \\
\hline $\begin{array}{l}\text { No }(\%) \text { heavy smokers } \dagger \\
95 \% \text { Confidence interval (\%) }\end{array}$ & $\begin{array}{c}225(37 \cdot 9) \\
34 \text { to } 42\end{array}$ & $\begin{array}{c}158(42 \cdot 4) \\
37 \text { to } 47\end{array}$ & $\begin{array}{l}51(58 \cdot 0) \\
48 \text { to } 68\end{array}$ & $\begin{array}{l}42(53 \cdot 8) \\
43 \text { to } 65\end{array}$ & $14 \cdot 8$ & $<0.0005$ & 1.91 & $1 \cdot 16$ to $3 \cdot 1$ \\
\hline
\end{tabular}

*Never snoring $v$ habitual snoring.

tDaily number of cigarettes smoked by parents was known for 922 children.

All of the parents who smoked had started smoking before the birth of the child. Prevalence of snoring was increased in children both from moderate smoking households $\left(\chi^{2}=13.4 ; \mathrm{p}<0.0005\right)$, and from heavy smoking households $\left(\chi^{2}=14.8 ; \mathrm{p}<0.0005\right)$. Prevalence of habitual snoring increased with the amount of cigarettes smoked $(8.8 \%$ in children from heavy smoking households (odds ratio $=1 \cdot 91 ; 1 \cdot 16$ to $3 \cdot 10$ ) compared with $8.6 \%(1.81 ; 1.08$ to 3.00$)$ and $5.5 \%$ in children whose parents were moderate smokers or never smokers, respectively). This dose related effect of passive smoking was significant $\left(\chi^{2}=9 \cdot 04 ; p<0 \cdot 005\right)$.

\section{Discussion}

We found that respiratory symptoms such as rhinitis and cough or phlegm production, a previous tonsillectomy, and passive parental smoking were associated with an increased prevalence of snoring. As far as we know this is the first report of the prevalence of snoring in a general population sample of children. The prevalence of snoring was $7 \cdot 3 \%$ in the overall sample. The accuracy of reporting snoring can be influenced by several factors. Firstly, reported snoring is arbitrarily defined. ${ }^{1-69} 9^{10}$ Secondly, questionnaire data may underestimate the true prevalence of snoring. ${ }^{6}$ Thirdly, as the subject is usually not aware of snoring answers mostly depend on the parent, and this bias can be further increased in children whose parents do not sleep in the same room. We have been able to reduce this bias only by excluding from the analysis children sleeping alone. The actual prevalence of snoring in children may be even higher than that observed.

Prevalence of snoring tended to decrease with age. As snoring depends on pharyngeal size $\mathrm{e}^{21}$ older children, because of larger pharyngeal cross sectional areas, may have a lower risk of snoring than younger children. In our sample prevalence of snoring was equal in boys and girls whereas a predominance of snoring in men is a common finding in adult populations. ${ }^{2.59} 10$ This discrepancy may be due to the prepubertal age of our sample. Testosterone has an apnoea promoting effect, ${ }^{22}$ whereas progesterone is a respiratory stimulant ${ }^{23}$ and may enhance activity of the pharyngeal dilator muscles. ${ }^{24}$ Thus these hormones may play respectively a positive and an inhibitory role in the development of snoring in men and in women. Moreover, it has been shown that prevalence of snoring increases progressively in men after 20 years of age, whereas in women this increase occurs only after 40 years of age. ${ }^{9}$

Rhinitis was associated with an increase in prevalence of snoring. Bloom and coworkers failed to find this relation in adults. ${ }^{10}$ Rhinitis has, however, been found more commonly in snoring children than in snoring adults, ${ }^{25}$ and it has been shown that high nasal airflow resistance can increase both the incidence of snoring ${ }^{26}$ and of obstructive sleep apnoea. ${ }^{27} 28$

A weak association was observed between snoring and asthma, but the risk of habitual snoring was not significantly increased in children with asthma. This result agrees with previous findings in an adult population. ${ }^{5}$ We observed a close association between snoring and cough or sputum production. Bloom and coworkers reported the same association in an adult population. ${ }^{10}$ After adjustment for passive smoking the relation was still significant. Chronic inflammation may result in a narrowing of pharyngeal size, leading to an increased risk of snoring.

A previous tonsillectomy was related to an increased risk of habitual snoring. This association was stronger in children exposed to passive smoking. This finding agrees with a previous study, which reported an association between parental smoking and tonsillectomy. ${ }^{29}$

The association between passive smoking and snoring was highly significant, and we observed a doseeffect relation between the number of cigarettes smoked by parents and the prevalence of habitual snoring. Smoking has been found to be a risk factor for snoring, ${ }^{510}$ and the risk is related to the amount of cigarettes smoked. ${ }^{10}$ Moreover, in former smokers the prevalence of snoring is dependent on the time since stopping. ${ }^{10}$ These data strongly suggest a chronic effect of smoking on the upper airways. ${ }^{10}$ As snoring depends on pharyngeal size ${ }^{21}$ smoking can provoke mucosal oedema and inflammation, ${ }^{7}$ resulting in a narrowing of the pharynx. This mechanism, which has been hypothesised in snoring adults who smoke, ${ }^{10}$ can also operate in children exposed to passive parental smoking since birth.

In conclusion, our findings show that snoring is quite common in children and is associated with the presence of rhinitis or cough and sputum production. Also it is closely related to passive parental smoking. The dose-effect relation of smoking and snoring strengthens this association. This report puts forward a further adverse effect of passive parental smoking on their children's health. Longitudinal studies should be conducted to assess the course of snoring in childhood related to the development of hypertension, cardiac disease, and the sleep apnoea syndrome.

We thank the parents and the teachers of the schools concerned in this study for their cooperation; Isabella Annesi and Francine Kauffmann for their helpful suggestions; Virginio Mandelli and Massimo Del Vita for statistical advice; and Francesco Forastiere, who provided the statistical packages.

1 Gislason T, Aberg $\mathrm{H}$, Taube A. Snoring and systemic hypertension-an epidemiological study. Acta Med Scand 1987;222:415-21.

2 Koskenvuo M, Kaprio J, Partinen M, Langinvainio H, Sarna S, Heikkila K. Snoring as a risk factor for hypertension and angina pectoris. Lamiet $1985 ; \mathrm{i}: 893-6$

3 Lugaresi E, Cirignotta F, Coccagna G, Piana C. Some epidemiological data on snoring and cardiocirculatory disturbances. Sleep 1980;3:221-4.

4 Mondini S, Zucconi M, Cirignotta F, et al. Snoring as a risk factor for cardiac and circulatory problems: an epidemiological study. In: Guilleminault C, Lugaresi E, eds. Sleep/wake disorders. Natural history, epidemiologv and longterm evolution. New York: Raven Press, 1983:99-105.

5 Norton PG, Dunn EV. Snoring as a risk factor for disease: an epidemiological survey. Br Med J 1985;291:630-2.

6 Koskenvuo M, Kaprio J, Telakivi T, Partinen M, Heikkila K, Sarna S. Snoring as a risk factor for ischaemic heart disease and stroke in men. BrMed f 1987;294:16-9.

7 Lugaresi E, Coccagna G, Farneti P, Mantovani M, Cirignotta F. Snoring. Electroencephalogr Clin Neurophysiol 1975;39:59-64. 
8 Guilleminault C, van den Hoed J, Mitler MM. Clinical overview of the sleep apnea syndromes. In: Guilleminault $\mathrm{C}$, Dement $\mathrm{W}$, eds. Sleep apnea syndromes. New York: Alan R Liss, 1978:1-12.

9 Lugaresi E, Coccagna G, Cirignotta F. Snoring and its clinical implications In: Guilleminault C, Dement W, eds. Sleep apnea syndromes. New York: Alan R Liss, 1978:13-21

10 Bloom JW, Kaltenborn WT, Quan SF. Risk factors in a general population for snoring. Importance of cigarette smoking and obesity. Chest 1988;93: $678-83$.

11 Guilleminault C, Eldridge FL, Simmons FB, Dement WC. Sleep apnea in eight children. Pediatrics 1976;58:23-30.

12 Guilleminault C, Winkle R, Korobkin R, Simmons B. Children and nocturnal snoring: evaluation of the effects of sleep related respiratory resistive load and davtime functioning. Eur 7 Pediatr 1982:139:165-71.

13 Mauer KW, Staats BA, Olsen KD. Upper airway obstruction and disordered nocturnal breathing in children. Mayo Clin Proc 1983;58:349-53.

14 Westbrook PR. The chronically snoring child: an acoustic annoyance or cause for concern? Mayo Clin Proc 1983;58:399.

15 Ferris BG. Epidemiology standardization project: children's questionnaire. Am Rev Respir Dis 1978;118(suppl):36-53.

16 Snedecor GW, Cochran WG. Statistical methods. 7th ed. Iowa: Iowa State University Press, 1980:215-33.

17 Mantel N. Chi-square test with one degree of freedom: extension of the Mantel-Haenszel procedure. Fournal of the American Statistical Association 1963;58:690-700

18 Cornfield J. A statistical problem arising from retrospective studies. In: Neyman J, ed. Proceedings of the third Berkeley symposium. Berkeley: University of California Press, 1956:133-48.

19 Mantel N, Haenszel W. Statistical aspects of the analysis of data from retrospectve studies of disease. Fournal of the National Cancer Institute $1959 ; 22: 719-48$

20 Robins J, Greenland S, Breslow NE. A general estimator for the variance of the Mantel-Haenszel odds ratio. Am $\mathcal{F}$ Epidemiol 1986;124:719-23.

21 Bradley TD, Brown IG, Grossman RF, et al. Pharyngeal size in snorers, nonsnorers, and patients with obstructive sleep apnea. $N$ Engl $\mathcal{Y ~ M e d ~}$ $1986 ; 315: 1327-31$

22 Sandblom RE, Matsumoto AM, Schoene RB, et al. Obstructive sleep apnea syndrome induced by testosterone administration. N Engl f Med 1983;308 508-10

23 Sutton FD, Zwillich CW, Creagh CE, Pierson DJ, Weil JV. Progesterone for outpatient treatment of Pickwickian syndrome. Ann Intern Med 1975;83 476-9.

24 Weil JV, Cherniak NS, Dempsey JA, et al. Respiratory disorders of sleep. Pathophysiology, clinical implications, and therapeutic approaches. Am Rev Respir Dis 1987;136:755-61.

25 Robin IG. Snoring Proceedings of the Royal Society 1968:61:575-82.

26 Hoffstein V, Chaban R, Cole P, Rubistein I. Snoring and upper airway properties. Chest 1988;94:87-9.
pofstein

27 McNicholas WT, Tarlo S, Cole P, et al. Obstructive apneas during sleep in patients with seasonal allergic rhinitis. Am Rev Respir Dis 1982;126:625-8.

28 Zwillich CW, Pickett C, Hanson FN, Weil JV. Disturbed sleep and prolonged apnea during nasal obstruction in normal men. Am Rev Respir Dis 1981;124:158-60.

29 Said G, Zalokar J, Lellouch J, Patois E. Parental smoking related to adenoidectomy and tonsillectomy in children. $f$ Epidemiol Commun Health 1978;32:97-101.

(Accepted 17 October 1989

\title{
Consequences and treatment of ovarian failure after total body irradiation for leukaemia
}

\author{
M P Cust, M I Whitehead, R Powles, Myra Hunter, S Milliken
}

\begin{abstract}
Objective-To assess the incidence and severity of physical and psychosexual symptoms in young women due to ovarian failure caused by total body irradiation for leukaemia and the women's response to hormone treatment.

Design-Postal questionnaire and interview.

Setting-Leukaemia unit of oncology hospital.

Patients-Consecutive series of 46 English speaking women who had developed ovarian failure after total body irradiation and bone marrow transplantation as treatment for leukaemia.

Results - Of the 36 responders, 33 reported some symptoms, vaginal dryness being the most common (29). This profoundly affected sexual function. Although 22 women had had sexual intercourse within six months after treatment, 16 were less interested in and 18 experienced difficulties with sexual intercourse. Anxieties about sterility, femininity, and appearance were common and reduced self confidence. Almost half reported that they had changed their social habits and restricted their social activities. Treatment seemed effective in abolishing symptoms in 24 women, but vaginal dryness remained a problem in three. Two women failed to respond and intercourse remained impossible.
\end{abstract}

Conclusions-Such patients are vulnerable and access to gynaecologists and endocrinologists soon after treatment would be valuable. The optimal treatment regimen and the long term benefits of treatment have yet to be established.

\section{Introduction}

Total body irradiation and bone marrow transplantation have recently become established treatments for certain types of leukaemia in younger patients. Because of the systemic nature of the disease, ' no attempt can be made to shield the gonads. Consequently, nearly all women develop amenorrhoea and permanent ovarian failure. As over half are likely to survive long term,,$^{23}$ recognition of the consequences of total body irradia- tion and premature ovarian failure are of great importance.

While there has been a recent expansion in our knowledge of the incidence and aetiology of all causes of premature ovarian failure ${ }^{4}$ little is known about the consequences. Various authors have commented on the presence of hot flushes, night sweats, and atrophy of the lower genital tract in patients with premature ovarian failure,${ }^{5.10}$ but some of these studies included patients who subsequently regained ovarian function spontaneously (and even became pregnant) and clearly, therefore, did not have irreversible ovarian failure. Furthermore, few previous studies have investigated the impact of oestrogen deficiency on sexual function and none on self esteem and social behaviour. We believe that such additional information is vitally important in clinically managing all patients with irreversible premature ovarian failure irrespective of aetiology.

We present data on some of the early consequences of ovarian failure and the effects of hormone therapy in a group of 36 women previously treated with total body irradiation and bone marrow transplantation for leukaemia.

\section{Patients and methods}

Forty six English speaking patients who had received total body irradiation and bone marrow transplantation at the leukaemia unit at the Royal Marsden Hospital were sent a questionnaire, to which 36 responded. All patients had received conditioning treatment with cyclophosphamide and total body irradiation or melphalan and total body irradiation. " The questionnaire referred to symptoms and concerns experienced by the patients in the six months after treatment.

Of those who responded to the questionnaire, 34 were referred to the unit from hospitals elsewhere in the United Kingdom (from as far afield as Cornwall in the south to the Orkney islands in the north); the two other patients were local. At the time of treatment the average age was $25 \cdot 7$ years (range 14.3 years to 42.6 years) and the mean time between treatment and 